July 2021

\title{
Antiracist School Counselor Preparation: Expanding on the Five Tenets of the Transforming School Counseling Initiative
}

\author{
Erin Mason \\ Georgia State University \\ Adrianne Robertson \\ Georgia State University \\ Jan Gay \\ University of Florida \\ Nkenji Clarke \\ Pennsylvania State University \\ Cheryl Holcomb-McCoy \\ American University
}

Follow this and additional works at: https://trace.tennessee.edu/tsc

Part of the Counselor Education Commons, and the Higher Education Commons

\author{
Recommended Citation \\ Mason, Erin; Robertson, Adrianne; Gay, Jan; Clarke, Nkenji; and Holcomb-McCoy, Cheryl (2021) "Antiracist \\ School Counselor Preparation: Expanding on the Five Tenets of the Transforming School Counseling \\ Initiative," Teaching and Supervision in Counseling: Vol. 3 : Iss. 2 , Article 2. \\ https://doi.org/10.7290/tsc030202 \\ Available at: https://trace.tennessee.edu/tsc/vol3/iss2/2
}

This article is brought to you freely and openly by Volunteer, Open-access, Library-hosted Journals (VOL Journals), published in partnership with The University of Tennessee (UT) University Libraries. This article has been accepted for inclusion in Teaching and Supervision in Counseling by an authorized editor. For more information, please visit https://trace.tennessee.edu/tsc. 


\title{
Anti-Racist School Counselor Preparation: Expanding on the Five Tenets of the Transforming School Counseling Initiative
}

\author{
E C M Mason, Adrianne C Robertson, Jan L Gay, Nkenji K Clarke, Cheryl Holcomb-McCoy
}

As a profession, school counseling must serve as an active force against systemic racism, and school counselor preparation must equip future professionals as anti-racist agents of change. This article expands the original Transforming School Counseling Initiative tenets that sought to re-envision school counselor preparation in the late 1990s with language that explicitly supports anti-racism. The authors offer a definition of anti-racist school counseling and sample assignments and experiences that align with the revised tenets.

Keywords: anti-racist training, school counseling, counselor education

The 2020 murders of Black lives by police, including the murders of George Floyd, Ahmaud Arbery, and Breonna Taylor, brought forth historic social unrest and a racial reckoning in the United States - an anti-Black pandemic alongside COVID19. Subsequently, many professions and educational institutions scrambled to prioritize long overdue and necessary calls to action related to historic oppression, systemic racism, and white supremacy. As a profession historically populated by White women, school counselors must come to terms with their part in upholding the status quo. Drawing on past work by scholars who introduced the school counselor's roles as leader and advocate, this conceptual article serves as a new vision of antiracist school counselor preparation.

Each of the five tenets of the Transforming School Counseling Initiative (TSCI) is presented with its previous and revised objectives, appropriate for use by counselor educators, school counseling coordinators, or school counselors in practice.

Additionally, the authors present sample assignments and experiences for each of the revised tenets, which are designed with school counselor preparation in mind but could be used in practice settings. The format of the revised tenets is designed as an experiential starting guide to antiracist school counselor preparation. By providing an outline of what anti-racist school counselor preparation can look like, the authors aim to spur the movement for anti-racist school counseling.

\section{Brief History of the Transforming School Counseling Initiative}

The TSCI, developed at the Education Trust in the late 1990s, overlapped with the launch of the No Child Left Behind Act (2001), which called for greater accountability and the remediation of achievement based on race, income, and other demographic factors. Spearheaded by Patricia J. Martin and Dr. Reese House, the TSCI was conceptualized as a means to champion a new vision for school counseling. More specifically, Martin and House wanted the initiative to focus on the attitudes, skills, and knowledge that professional school counselors need to successfully transition from preservice to practice. TSCI challenged the traditions of school counselor preparation and practice through five tenets: (a) leadership, (b) advocacy, (c) teaming and collaboration, (d) counseling and coordination, and (e) use of data and assessment (Sears, 1999, The Education Trust, 2009). Martin stated that the TSCI or the "new vision" for school counseling was designed to "move school counseling from a position of comfort or maintaining status quo to one of cutting-edge social action, advocacy for access and support for success for all students, especially those that have 
not been served well in the past" (2002, p. 152). Notably, the TSCI was intended to extend the school counselor's role with student achievement by emphasizing the need for school counselors to audit schoolwide data, highlight inequities, and influence systemic change.

A major component of the TSCI included its focus on school counselor preparation. In 1997, the Education Trust selected six university/school district partnerships to fund and develop model programs to transform school counselor preparation. Those six universities - California State UniversityNorthridge, Indiana State University, the Ohio State University, State University of West Georgia, University of Georgia, and University of North Florida - piloted the TSCI framework into their graduate programs along with partner school districts (Martin, 2002). As a result of the university partnerships, new preparation models and skills for trainees were introduced. Hayes and Paisley (2002) specifically recommended a "cohort" model in addition to the following school counselor trainee competence areas: consultation and coordination, multiculturalism, teaming and collaboration, advocacy, leadership, and the use of technology to facilitate change. The TSCI and its founders (House \& Martin, 1998) are an important part of our history because they brought forward new ideas about the role of the school counselor and counselor training (Pérusse \& Colbert, 2007). Although the TSCI in the 1990s and early 2000s outlined for school counselors their role in education reform, can its tenets also be used to outline school counselors' role in anti-racism?

\section{Expanding the TSCI Tenets}

Expanding the TSCI tenets includes (a) revising the language used to describe them and (b) integrating them into school counselor preparation. Education, as it exists in the United States, is an inherently racist system (Valant, 2020). Without first acknowledging this, there is no hope of dismantling the systemic racism that continues to advantage some and disadvantage others. School counselors must understand that the "school" part of being a "school counselor" includes helping students via anti-racist work at a systems level.

Counselor preparation in the United States has traditionally followed a White male, Westernized individualistic paradigm (Seward, 2014) in which autonomy is valued, and the client, with the support of the counseling relationship, is ultimately responsible for change. This is problematic for school counseling because it assumes that the problem lies with the student. However, children and adolescents are still developing as individuals, and in society, they already have marginalized status. Furthermore, school counselors spend a great deal of time daily working beyond the student level within multiple systems to provide an intentional set of services designed to meet students' academic, career, social, emotional, and mental health needs (McMahon et al., 2014).

The American School Counselor Association (ASCA) National Model (2003) has helped define school counseling practice and the use of data to advocate for and document change. The tenets were integrated into the first edition of the model coauthored by Dr. Judy Bowers and Dr. Trish Hatch and also proliferated by many counselor educators (Dahir et al., 2016; Dahir \& Stone, 2012; Erford, 2018). To prepare school counselors to do more anti-racist work, we believe the TSCI tenets provide a familiar and natural framework. Central to our revision to the TSCI tenets is the notion that school counselors must assume deficits in the system (i.e., school) rather than in students and that they must be prepared to do at least as much systems change work as direct counseling. While graduate programs should include similar training with respect to counseling skills for all graduate students, school counselors must receive training in systems change, and that is often what programs lack. We have revised the TSCI tenets with an emphasis on systems work. In the words of Dr. Peggy Hines, the former director of the National Center for Transforming School Counseling, "If school counselors can get schools to change policy and practice, and support those kinds of systemic interventions for students, then that's going to be a lot more effective than trying to change kids one at a time" (Pérusse \& Colbert, 2007 p. 478).

\section{Revising the TSCI Tenet Language}

Based on our collective experience as school counselors and scholars, we define anti-racist school counseling as "school counselors' active approach to dismantling racist practices, racial 
hatred, systemic racism, and oppression of historically oppressed racial groups within educational systems" (Holcomb-McCoy, in press). By this definition, we understand much of this work to happen in a professional context, however, we also believe that school counseling professionals can and must combat racism in their personal contexts as well — within themselves and among others. We also view anti-racism as deliberate steps that school counselors take to provide equitable opportunities for all students on an individual and systemic level. Therefore, an anti-racist identity requires congruence of thought and action in all aspects of one's life.

Revisions to the tenets aim to (a) provide greater detail and clarity, (b) emphasize systemic actions school counselors should take, and (c) use bolder, stronger words to evoke dynamism and activism. To support the revised tenets, we provide considerations for structuring graduate programs and pedagogy around anti-racist and equitable practices. The tenets then provide a roadmap of student learning goals. The sample assignments and experiences detail how these goals might be met (see Table 1).

\section{Integration of the Tenets into School Counselor Preparation}

According to the Council for Accreditation of Counseling and Related Educational Programs (CACREP) 2016 standards, all counseling programs should orient students to advocacy processes that address institutional and social barriers that impede access, equity, and success for all clients (CACREP, 2016, F.1.e). Counseling programs are obligated to prepare counselors in training to recognize and understand how to implement strategies for eliminating barriers, prejudices, and processes of intentional and unintentional oppression and discrimination (CACREP, 2016, F.2.h). More specifically, school counseling specialty programs are required to prepare those in training to promote equity in student achievement and postsecondary success and to use data to advocate for programs and students (CACREP, 2016, G.3.k \& o). The ASCA Standards for School Counselor Preparation Programs under Council for the Accreditation of Educator Preparation (CAEP) (2019b) include reference to the tenets (Standard 6, Professional Practice) as do the ASCA Ethical Standards for School Counselors (2016) (e.g., A6, A10). Therefore, it is imperative that school counselor educators center their programs around principles of anti-racist practice.

\section{Anti-Racist Program Structure}

A first step for faculty is to reflect on the antiracist extent of their own practices as well as that of the overall culture and practices of the program (Kishimoto, 2018). Programs should revise course policies, practices, mission, and vision statements to include culturally responsive language. School counselor educators must review course syllabi and assignments regularly for inclusivity and ensure a training process that values anti-racism. Another critical component school counselor preparation programs ought to examine is the recruitment effort for diverse students and the ability to support students of Color in the program (Remley \& Pusateri, 2019). The following are some considerations for moving toward an anti-racist program structure:

- Shift to test-optional admissions.

- Reduce course and material fees.

- Provide formal mentoring opportunities for students in and out of the program to give access to diverse models in the field.

\section{Anti-Racist Pedagogy}

To transform school counselor preparation into anti-racist school counselor preparation, programs must explore methods for infusing experiential, real-world learning activities that increase all school counselors in training (SCIT) abilities to identify and disrupt systems of oppression. Counselor educators can incorporate experiential learning activities that link abstract concepts to concrete experiences (Bohecker \& Doughty Horn, 2016) and that challenge students to dig deeper into their personal beliefs and inherent biases (Green et al., 2014). According to Ockerman and Mason (2012), service learning is a valuable way for students to connect what they learn in the classroom to their work within schools and surrounding communities. 
Graduate programs should prepare future school counselors for leadership, advocacy, teaming, collaboration, counseling, and data use (Sears, 1999) to promote anti-racism. Counselor educators must introduce the reality of systemic racism in schools early in the program and continue to emphasize the role that racism plays in the education system. Thus, programs should prioritize hands-on learning experiences that can be supplemented by key readings and speakers. Assessment beyond knowledge to skills means that counselor educators need to shift away from traditional assignments that emphasize traditional standards of the academy (e.g., long research

\section{Table 1. Revised Tenets of the Transforming School Counseling Initiative (TSCI)}

\begin{tabular}{|c|c|c|}
\hline & Original & Revised \\
\hline Leadership & $\begin{array}{l}\text { Promote, plan, implement programs } \\
\text { (i.e., academic, social/emotional, } \\
\text { college, and career) } \\
\text { Provide data on student outcomes } \\
\text { showing achievement gaps } \\
\text { Arrange school mentoring to } \\
\text { provide students support for success } \\
\text { Play a leadership role in carrying } \\
\text { out counseling functions }\end{array}$ & $\begin{array}{l}\text { Establish an identity as a leader by } \\
\text { seeking allies and mentors, actively } \\
\text { participate in decision-making at } \\
\text { the local school level, and lead } \\
\text { efforts that promote equity and } \\
\text { antiracism } \\
\text { Engage in the school community } \\
\text { and professional development that } \\
\text { supports your work and grows } \\
\text { leadership skills (i.e., state } \\
\text { professional association, } \\
\text { volunteering) } \\
\text { Champion student-centered, } \\
\text { student-designed, and student-led } \\
\text { programming to target opportunity } \\
\text { gaps, student needs, school climate, } \\
\text { and college and career }\end{array}$ \\
\hline Advocacy & $\begin{array}{l}\text { Make data available to help the } \\
\text { whole school look at student } \\
\text { outcomes } \\
\text { Use data to affect change, calling on } \\
\text { resources from the school and } \\
\text { community } \\
\text { Advocate for students' experiences } \\
\text { to broaden career awareness } \\
\begin{array}{l}\text { Advocate for students' course } \\
\text { placement and support for rigorous } \\
\text { preparation }\end{array}\end{array}$ & $\begin{array}{l}\text { Expose spoken or written racist } \\
\text { language, microaggressions, or } \\
\text { implicit bias in the school setting } \\
\text { Identify and dispute policies and } \\
\text { practices that marginalize students, } \\
\text { propose suggested revisions and } \\
\text { rationales with administration, } \\
\text { strategize with data, and be } \\
\text { persistent } \\
\text { Challenge school staff through data } \\
\text { on opportunity gaps and deliver } \\
\text { professional development that } \\
\text { dismantles racist beliefs and } \\
\text { practices } \\
\text { Scale up data presentations and } \\
\text { advocacy efforts to the district, } \\
\text { school board, and legislative or } \\
\text { state level with support from allies }\end{array}$ \\
\hline
\end{tabular}


Table 1. continued

\begin{tabular}{|c|c|c|}
\hline Teaming and Collaboration & $\begin{array}{l}\text { Work with problem-solving teams } \\
\text { to ensure responsiveness to equity } \\
\text { and diversity } \\
\text { Collaborate with others (i.e., } \\
\text { teachers, admin, community) } \\
\text { Collaborate with school and } \\
\text { community team to focus on } \\
\text { rewards and incentives for student } \\
\text { achievement } \\
\text { Collaborate with others to develop } \\
\text { staff training on students' needs } \\
\text { (i.e., social/emotional, } \\
\text { developmental) }\end{array}$ & $\begin{array}{l}\text { Invest time in developing } \\
\text { relationships in the school building, } \\
\text { understand the dynamics and } \\
\text { responsibilities of departments, } \\
\text { learn the demands of each role, and } \\
\text { promote the role of the school } \\
\text { counselor } \\
\text { Ensure all stakeholders are } \\
\text { equitably represented in decision- } \\
\text { making processes in the counseling } \\
\text { program including students } \\
\text { Network with community groups, } \\
\text { and invite and involve them in } \\
\text { schoolwide decision-making }\end{array}$ \\
\hline Counseling and Coordination & $\begin{array}{l}\text { Hold brief counseling sessions with } \\
\text { individuals, groups, and families } \\
\text { Coordinate school and community } \\
\text { resources } \\
\text { Be a liaison between students and } \\
\text { staff, setting high aspirations for all } \\
\text { Coordinate staff training to address } \\
\text { student needs schoolwide }\end{array}$ & $\begin{array}{l}\text { Implement culturally sustaining } \\
\text { direct and indirect counseling } \\
\text { services, including broaching, as } \\
\text { part of a comprehensive program } \\
\text { with a strengths-based approach for } \\
\text { all students } \\
\text { Empower students with strategies to } \\
\text { advocate for themselves and others } \\
\text { Maintain and publicize a thorough } \\
\text { list of resources to support students } \\
\text { and families with a variety of issues } \\
\text { including mental health as well as } \\
\text { those related to societal } \\
\text { marginalization and oppression } \\
\text { (i.e., housing, civil rights, } \\
\text { immigration legal supports, } \\
\text { LGBTQ+, disability services) }\end{array}$ \\
\hline Assessment and Use of Data & $\begin{array}{l}\text { Assess and interpret } \text { student needs, } \\
\text { recognizing differences in culture, } \\
\text { language, values, and backgrounds } \\
\text { Establish and assess measurable } \\
\text { goals for student outcomes from the } \\
\text { counseling program } \\
\text { Assess barriers that impede } \\
\text { learning, inclusion, and academic } \\
\text { success } \\
\text { Interpret student data for use in } \\
\text { whole school planning }\end{array}$ & $\begin{array}{l}\text { Regularly examine data to identify } \\
\text { the contexts, characteristics, and } \\
\text { needs of students, and consider first } \\
\text { potential systemic barriers to } \\
\text { success } \\
\text { Denounce a deficit-based approach, } \\
\text { endorse evidence-based } \\
\text { interventions that examine, and } \\
\text { disrupt inequities in the system } \\
\text { Promote the school counseling } \\
\text { program as an agent for creating } \\
\text { more equitable policies and } \\
\text { practices within the school }\end{array}$ \\
\hline
\end{tabular}


papers) and focus more on assessments that prepare SCITs for the practical demands of the job (e.g., projects that explore real solutions to creating systemic change). The following are some considerations for moving toward anti-racist pedagogy:

- Audit and diversify course materials and speakers, prioritizing BIPOC scholars and guests.

- Present traditional theories and those that are emerging or lesser known and encourage discussion of how dominant pedagogies have colonized the profession.

- Allow choice in assignment types to meet course objectives.

- Ensure clinical placements are diverse and supervisors can model anti-racist school counseling practices.

\section{Sample Activities and Experiences}

The following sample activities and experiences are presented with direct connections to the revised TSCI tenets. Each example can be modified for either content-based or clinical courses and for earlier or later developmental stages of the student. We emphasize experience and/or skill development with the expectation that readings, materials, or guest speakers would be carefully selected as supplementary elements to address knowledge standards.

\section{Leadership}

The National Center for Transforming School Counseling (The Education Trust, 2009) emphasized the need for school counselors to be effective leaders, who specialize in the academic, social, emotional, personal development, and career planning needs of students. Given the need to support all students, especially those impacted by opportunity gaps, school counselors must attend to those who are systematically denied quality education meant to lead them toward pathways of success. Furthermore, SCITs learning to take the lead with an anti-racist approach will increase their quality relationships with students and the school community, students' sense of belonging, and higher levels of academic success and equity (Logan \& Scarborough, 2008). However, SCITs need direction throughout their school counseling program about how to embody leadership and invest in their leadership development needs (Dollarhide, 2003).

\section{Establish a Leadership Identity}

One way counselor educators can support SCITs' leadership identity development is to have an assignment in which they interview current leaders of the state school counselor association. The learning objective is to connect with a leader in the field and learn about the trajectory of leadership development and then reflect on their own leadership abilities and skills. Suitable for an introduction to school counseling course, counselor educators may choose to allow students to collaboratively develop a question bank for the interviews. Faculty can also offer options for the final product, which could include papers, videos, or a collaborative representation of themes of the data collected from all the interviews. Alternatively, counselor educators may wish to engage students in coming up with other ways to demonstrate their learning such as designing a leadership plan.

\section{Champion a Counseling Group}

Counselor educators can encourage students' ability to approach administration by having them design a brief proposal for a small group for a population of marginalized students. The learning objective is for SCITs to develop persuasive, datadriven proposals. Proposals should include research or national data that supports the need for the group, a basic design of the intervention, any connections to the school's mission, and the overall purpose and goals. Students might complete this in an Introduction to School Counseling or Group Counseling course with their own school experiences in mind, or those in clinical experiences could complete this as part of being on site. Faculty could include reading materials aligned with the lived experiences of the group of marginalized students and/or literature on school counseling groups for marginalized students. Class time might be spent providing individual and/or group feedback on proposals or mock pitches. In addition, faculty can include a class discussion with school principals about strategies for working effectively with administration to serve all students.

\section{Advocacy}


Preparing SCITs for advocacy is a critical component of systems change work. Counselor education programs can help foster an identity of advocate by infusing advocacy competencies into the curriculum and clinical experiences. School counselors have an ethical obligation to center advocacy around the identification of school system policies that negatively impact student success (Stone \& Zirkel, 2010). Advocacy competence should be taught to SCITs to increase their ability to advocate ethically and effectively (Toporek et al., 2009). SCITs should be encouraged to practice advocacy skills at their clinical sites so they become comfortable using advocacy skills in a culturally responsive manner (Dixon et al., 2010). Infusing advocacy across all school counseling courses will allow SCITs to develop an advocate identity over time. It is imperative that SCITs are trained in effective advocacy strategies to prevent them from being unsuccessful in advocating for all students (Haskins \& Singh, 2016). Creating relevant opportunities across the program will provide SCITs practice with advocacy and increase their level of self-efficacy as change agents. Furthermore, understanding policy is preparation for SCITs to develop an anti-racist lens when serving students from various communities and becoming leaders within the profession (Dollarhide, 2003).

\section{Closing the Gap}

One way counselor educators can increase SCITs' advocacy competence is to have students design an advocacy project based on the ASCA Closing the Gap action plan. The learning objective is to use schoolwide data to identify opportunity gaps and provide targeted interventions to advocate for marginalized students. SCITs can complete portions of the template in earlier courses such as Introduction to School Counseling by reviewing publicly available data from local schools.

However, a Closing the Gap assignment is most appropriate for clinical experiences when students can use data from their own sites and deliver interventions themselves. This allows the SCIT to have an advocacy-focused site experience. Faculty can work with local school counselors to utilize the ASCA Closing the Gap action plans with interns. At the end of the project, SCITs can present their results report to the class as well as to stakeholders at their site. This activity helps build SCITs' selfefficacy (Bandura \& Schunk, 1981) in identifying and reducing achievement gaps. Aligning with relational pedagogy (MacNeill \& Silcox, 2006), counselor educators can add a journaling component to the activity to allow for a deeper interpersonal understanding among students while providing opportunities for feedback (DornMedeiros et al., 2020).

\section{Policy Investigation}

SCITs must understand that systemic racism is often embedded into policies. Within the context of a course like ethics, counselor educators can have students research a particular school policy that they experienced or know to be racist or inequitable. The learning objective is to know how and where to locate policies and how to read them as manifestations of racist and white supremacist belief systems. Students who are not yet in clinical placements may wish to research a policy from a school they attended or one for a local district that may be in the media. Students can present formally or informally to the class on the policy itself, previous versions, the historical context of the policy, and any consequences it has had. Faculty can then have SCITs rewrite the policy as they think it should read for the current time. A class session can be spent engaging students in deciding what might be done with the revisions, who should receive them, and what the outcomes might be.

\section{Teaming and Collaboration}

School counselors collaborate with all stakeholders (e.g., students, families, communities, and school personnel) where they can promote equity and access for all students (Tuttle et al., 2018). ASCA's Professional Standards and Competencies (2019a) include collaboration as a specific behavior that school counselors use to implement a comprehensive school counseling program. As an example, school nurses can impact student wellness, but they might not be considered when discussing how to collaborate in anti-racist school counseling. During their clinical experiences, SCITs attend staff meetings, but this 
may be the most interaction they have with school nurses. Bohnenkamp et al. (2015) reported that school nurses spend approximately $33 \%$ of their time addressing mental health issues. Still, school nurses are often not included in the student service team (Tuttle et al., 2018). Collaboration with the school nurse is one way for SCITs to include another professional voice when considering if race is a potential factor in student mental health.

\section{Develop Relationships in the School}

Counselor educators can introduce SCITs to the collaboration model outlined by Tuttle et al. (2018) as an example of developing relationships in schools. An example experiential activity that can be used to build SCITs collaboration skills is to invite school nurses and facilitate discussions about the partnership between the two groups of professionals. In a course such as consultation, the learning objective is to understand the benefits of developing relationships, predict any potential barriers to collaboration, and understand ways to navigate those barriers. SCITs in clinical placements can partner with school nurses to provide staff training on mental and physical health issues that disproportionately impact students and families of Color. Objectives might include how different cultures view mental health and how physiological symptoms can be signs of mental health issues. Although the above example is specific to collaboration with school nurses, it is critical to reiterate that school counselors must collaborate with all stakeholders in schools when developing relationships. Presentations from the partnership or reflections on the experiences could be submitted as assignments.

\section{Community Networking}

Teaming and collaboration can also be enhanced by having students engage beyond the school setting with community organizations. For this experiential activity, the objective is to learn more about an organization or cause that enhances one's development as a school counselor and that serves as a potential resource to the school. This would be appropriate for a content course like multicultural counseling, or it could be embedded across multiple semesters of the clinical experience. Students locate agencies within the community for their clinical sites that support anti-racist, cultural, economic, or legal initiatives. Examples might include shelters for homeless youth, scholarship programs that assist low-income students with college applications, or thrift stores that support refugee families. Faculty can then allow for in-person and/or virtual engagement and for each student to contract a project goal (e.g., 20 hours of service, volunteer for two events) and time to complete the goal based on availability. The final product can be presented in a paper or as a class presentation, or counselor educators can enlist the class in deciding other ways of demonstrating knowledge learned from this experience.

\section{Counseling and Coordination}

Some of the essential activities school counselors must provide are direct and indirect counseling services (ASCA, 2019a). It is necessary for school counselors to be trained in empowering students by uplifting their identities and inviting conversations about race, ethnicity, and diverse cultures (Smith et al., 2014); this includes the skill of broaching (DayVines et al., 2007). Another essential activity of school counselors includes coordinating community resources for students and families, informing them of outside-of-school service providers, agencies, and organizations (ASCA, 2019a), as research indicates that access to school counseling resources and services benefit students' mental health, college readiness, and overall educational outcomes (Dimmitt \& Wilkerson, 2012). School districts with families of lower socioeconomic status and of marginalized youth have a decreased access to necessary services despite students' capabilities (Dimmitt \& Wilkerson, 2012). To continue the work of anti-racism, school counselors must be fully inclusive in maintaining updated referral resources and community resources, knowledge of school and district policies, and trends in academic, social/emotional, career, and mental health supports.

\section{Broaching in the Counseling Session}

Broaching places responsibility on the counselor to acknowledge and incorporate race, ethnicity, and culture into the counseling relationship (Day-Vines, 2007). Faculty must help SCITs develop an antiracist stance through broaching behavior, which is a consistent openness and commitment to exploring Teaching and Supervision in Counseling * $2021 *$ Volume 3 (2) 
issues of diversity. This vital concept helps establish rapport within the counseling relationship, credibility on race and representation, and recognition that racism does impact students' experiences every day (Day-Vines, 2007). An assignment to support broaching behavior can be implemented in a skills course after learning the definition and multiple examples of broaching techniques. SCITs can reflect and write about what it means to express all of their identities freely and what it was like to be supported (or not) by their own K-12 educators. The learning objective is for SCITs to increase their awareness for centering diverse student identities and to know how to create the safest possible space for their students. Using a prospective or current school site, students will consider the experience of students of Color and write a reflection about the various implications if that student is not able to fully express their identities. Reflections should highlight institutional barriers impacting their social and emotional wellbeing; decision-making and coping skills; problemsolving; and levels of empowerment and resilience (Day-Vines et al., 2020). Based on any potential negative impact, SCITs can create counseling questions to explore needs of the student while specifically centering their identities. SCITs can continue to strengthen their broaching behaviors in their clinical experiences through role-play and discussion as part of case presentations during supervision.

\section{Resource Mapping}

One way school counselors can dismantle systemic racism is to serve as an access point for students and families for other needed services. School counselors are only as effective in this role to the extent they are knowledgeable about what is available in the community. SCITs in a consultation course and certainly clinical experiences can map out the resources in a school's surrounding community. Faculty can have students decide the categories (i.e., shelter, food, employment, summer enrichment) of resources and the type of outcome (i.e., brochure, webpage, interactive map). Final products can be presented to the school counselors and/or administrators at sites for practical use. The learning objective is for SCITs to acknowledge their role as liaisons for students, families, and staff and the resources in the surrounding community. Moreover, SCITs must begin to promote anti-racist action by combating issues involving lack of access and systemic barriers impacting their most marginalized students through the connection to supportive resources (Hayes \& Paisley, 2002).

\section{Data-Driven Activities}

Data-driven school counseling can positively impact student achievement (Dimmit et al., 2007), and SCITs can learn how to use data to drive their decision-making within a comprehensive school counseling program. School counselor educators can infuse data-based activities into multiple school counseling courses such as introduction to school counseling, group counseling, leadership and advocacy, college and career, and practicum and internship. The Closing the Gap project mentioned earlier in the Advocacy section can also be used as an assessment and use of data activity.

\section{School Community Profile}

One example of a data-driven activity counselor educators can facilitate is to have SCITs select a school and create a school community profile. For this activity, students will utilize accessible data on the school and the community it serves. Students can interview the school counselor, leadership team, and community members to create a report accurately representing the school and the community. The objective of this activity is to enhance SCIT self-efficacy using data while introducing multiple sources of data. Counselor educators may find that this activity can provide several learning opportunities for SCIT. One consideration is the number of schools in the area. If the counselor educator is working in a rural setting with fewer school districts, then this may be a group assignment instead of an individual project. This activity could provide opportunities for service learning as SCITs identify potential needs of school and community. This activity could be used in an introduction to school counseling course or a designated data-driven course.

\section{Denounce the Deficit Model}


Educators can be quick to use data to identify problems in groups of students (i.e., decreases in test scores, drops in graduation rates) or individual students (i.e., not meeting IEP goals, falling behind in homework completion). Preparing school counselors from an anti-racist perspective means teaching them to challenge this deficit model. In a course such as introduction to school counseling, group counseling, or consultation, faculty can provide SCITs with sample school data. Students can then identify a particular area of focus (e.g., attendance, behavior, academics) for intervention but have them design it for school staff rather than students. The intervention can include plans for collecting attendance and outcome data, as well as participant feedback. Students may share their proposed interventions with the class, discussing how intervening first or only with students can support a deficit model rather than systemic change. Students in clinical placements can do this based on data from their sites and, with permission, implement the intervention and collect the data.

\section{Evidence-based Assessment}

An anti-racist approach includes being knowledgeable of the norming process and samples used for testing common educational programs and assessments. Schools and districts frequently adopt tools that claim to be evidence-based. However, evidence-based may not be a term that applies to a population on which the program or assessment has not been widely tested. Faculty can have students research a program or assessment being used in local schools. As part of the research process, students can identify the populations with which the tool has been tested, to what extent, and to look for potential gaps. Students can prepare a collaborative presentation with key findings from each tool and present it to a panel of local school counselors. Alternatively, interns can take their findings to their site supervisors and strategize how best and with whom to share the information.

\section{Conclusion}

Anti-racist school counseling, especially where it requires interrupting systems, is not necessarily an intuitive practice, nor is it explicitly taught in graduate programs. Furthermore, it may not be comfortable, especially for graduate students who have privileged backgrounds or a limited idea of what it means to "help kids." While the context of every graduate program is unique, anti-racism must be foundational to all school counselor preparation. The revised tenets of the TSCI provide a roadmap for school counselor preparation programs that is both clear in its purpose and design but also flexible in its implementation. Anti-racist school counselor preparation is essential to evolving the profession as a whole and shifting the role to one that is as skilled in addressing systems as it is in counseling students.

\section{References}

American School Counselor Association. (2003). The ASCA national model: A framework for school counseling programs.

American School Counselor Association. (2016). ASCA ethical standards for school counselors.

American School Counselor Association. (2019a). ASCA school counselor professional standards \& competencies.

American School Counselor Association. (2019b). ASCA standards for school counselor preparation (ASCA CAEP SPA).

Bandura, A., \& Schunk, D. H. (1981). Cultivating competence, selfefficacy, and intrinsic interest through proximal self-motivation. Journal of Personality and Social Psychology, 41(3), 586598. https://doi.org/10.1037/0022-3514.41.3.586

Bohecker, L., \& Doughty Horn, E. A. (2016). Increasing students' empathy and counseling self-efficacy through a mindfulness experiential small group. Journal for Specialists in Group Work, 41(4), 312-333. http://dx.doi.org/10.1080/01933922.2016.1232322

Bohnenkamp, J. H., Stephan, S. H., \& Bobo, N. (2015). Supporting student mental health: The role of the school nurse in coordinated school mental health care. Psychology in the Schools, 52(7), 714 727. http://dx.doi.org/10.1002/pits.21851

Council for Accreditation of Counseling and Related Educational Programs. (2016). Policy document. http://www.cacrep.org/wpcontent/uploads/2017/07/2016-Policy-Document-July-2017.pdf

Dahir, C. A., \& Stone, C. B. (2012). The transformed school counselor (2nd ed.). Brooks/Cole Cengage Learning.

Dahir, C. A, Hatch, T., \& Tyson, L. E. (2016). Comprehensive school counseling programs. In B. T. Erford (Ed.), Professional school counseling: A handbook of theories, programs, and practices. (3rd ed., pp. 127-144). PRO-ED, Inc.

Day-Vines, N. L., Cluxton-Keller, F., Agorsor, C., Gubara, S., \& Otabil, N. A. A. (2020). The multidimensional model of broaching behavior. Journal of Counseling \& Development, 98(1), 107118. https://doi.org/10.1002/jcad.12304

Day-Vines, N., L., Wood, S. M., Grothaus, T., Craigen, L., Holman, A., Dotson-Blake, K., \& Douglass, M., J. (2007). Broaching the subjects of race, ethnicity, culture during the counseling process. Journaling of Counseling \& Development, 85 (4), 401-409.

Dimmitt, C., Carey, J. C., \& Hatch, T. (2007). Evidence-based school counseling: Making a difference with data-driven practices. Corwin Press.

Dimmit, C., \& Wilkerson, B. (2012). Comprehensive school counseling in Rhode Island: Access to services and student outcomes. Professional School Counseling, 16, 125-135.

Dixon, A., Tucker, C., \& Clark, M. (2010). Integrating social justice advocacy with national standards of practice: Implications for

Teaching and Supervision in Counseling * $2021 *$ Volume 3 
school counselor education. Counselor Education and Supervision, 50(2), 103-115. https://doi.org/10.1002/j.15566978.2010.tb00112.x

Dollarhide, C. T. (2003). School counselors as program leaders: Applying leadership contexts to school counseling. Journal of Professional School Counseling, 6(5), 304-308.

Dorn-Medeiros, C. M., Christensen, J. K., Lértora, I. M., \& Croffie, A. L. (2020). Relational strategies for teaching multicultural courses in counselor education. Journal of Multicultural Counseling and Development, 48(3), 149-160. https://doi.org/10.1002/jmcd.12174

Erford, B. T. (2018). Transforming the school counseling profession (5th ed.). Pearson.

Haskins, N. H., \& Singh, A. (2016). Advocacy competency of school counselors: An exploratory factor analysis. Professional School Counseling, 20(1), 1096-2409. https://doi.org/10.5330/10962409-20.1.149

Hayes, R. L., \& Paisley, P. O. (2002). Transforming school counselor preparation programs. Theory Into Practice, 41(3), 169-176. https://doi.org/10.1207/s15430421tip4103 5.

Holcomb-McCoy, C. (in press). The pathway to antiracism: Defining moments in counseling history. In C. Holcomb-McCoy (ed.), Antiracist counseling in schools and communities. American Counseling Association.

House, R. M., \& Martin, R J. (1998). Advocating for better futures for all students: A new vision for school counselors. Education, 119, 284-291.

Kishimoto, K. (2018). Anti-racist pedagogy: From faculty's self-reflection to organizing within and beyond the classroom. Race, Ethnicity and Education, 21(4), 540-554.

Logan, W., \& Scarborough, J. L. (2008). Connections through clubs: Collaboration and coordination of a school-wide program. Professional School Counseling, 12, 157-161.

Martin, P. J. (2002). Transforming school counseling: A national perspective. Theory Into Practice, 41(3), 148. https://doi.org/10.1207/s15430421tip4103_2

McMahon, H. G., Mason, E. C. M., Daluga-Guenther, N., \& Ruiz, A. (2014). An ecological model of professional school counseling. Journal of Counseling \& Development, 92(4), 459-471. https://doi.org/10.1002/j.1556-6676.2014.00172.x

MacNeill, N., \& Silcox, S. (2006, February). Pedagogic leadership: An alternative view of school leadership. Perspectives, 1 .
No Child Left Behind (NCLB) Act of 2001, Pub. L. No. 107-110, § 101, Stat. 1425 (2002).

Ockerman, M. S., \& Mason, E. C. M. (2012). Developing school counseling students' social justice orientation through service learning. Journal of School Counseling, 10(5). http://jsc.montana.edu/articles/v10n5.pdf

Pérusse, R., \& Colbert, R. D. (2007). The last word: An interview with Peggy Hines, Director of the Education Trust's National Center for Transforming School Counseling. Journal of Advanced Academics; Thousand Oaks, 18(3), 477-488, 490.

Remley, T. P., \& Pusateri, C. G. (2019). Ethical and legal issues for counselor educators. In L. R. Haddock \& J. S. Whitman (Eds.), Preparing the educator in counselor education: A comprehensive guide to building knowledge and developing skills (pp. 35-58). Routledge.

Sears, S. (1999). Transforming school counseling: Making a difference for students. NASSP Bulletin, 83(603), 47-53. https://doi.org/10.1177/019263659908360308

Seward, D. X. (2014). Multicultural course pedagogy: Experiences of master's-level students of color. Counselor Education and Supervision, 53(1), 62-79. http://dx.doi.org/10.1002/j.15566978.2014.00049.x

Smith, L. C., Geroski, A. M., \& Tyler, K. B. (2014). Abandoning colorblind practice in school counseling. Journal of School Counseling, 12(16). http://jsc.montana.edu/articles/v12n16.pdf

Stone, C., \& Zirkel, P. (2010). School counselor advocacy: When law and ethics may collide. Professional School Counseling, 13(4), 244-247. https://doi.org/10.5330/psc.n.2010-13.244

The Education Trust. (2009). The new vision for school counselors: Scope of work. http://edtrust.org/resource/the-new-vision-forschool-counselors-scope-of-the-work/

Toporek, R. L., Lewis, J. A., \& Crethar, H. C. (2009). Promoting systemic change through the ACA advocacy competencies. Journal of Counseling and Development, 87(3), 260-268. https://doi.org/10.1002/j.1556-6678.2009.tb00105.x

Tuttle, M., Yordy, M., Appling, B., \& Hanley, E. (2018). School counselor and school nurse collaboration: Partnering for K-12 student success. Journal of School Counseling, 16(4). https://jsc.montana.edu/articles/v16n4.pdf

Valant, J. (2020, June 4). The banality of racism in education. Brookings. https://www.brookings.edu/blog/brown-center-chalkboard/2020/06/04/the-banality-of-racism-in-education/ 